\title{
Pemeriksaan Kinerja BPK RI Atas Perjanjian Skema Kerjasama Pemerintah Dengan Badan Usaha (KPBU)
}

\section{Audit of BPK RI Performance on the Cooperation Scheme Agreement between the Government and Business Entities (KPBU)}

\author{
Irdham Riyanda
}

irdhamriyanda@yahoo.com

Badan Pemeriksa Keuangan Lampung

Submitted: Mar 2, 2020; Reviewed: Mar 26, 2020; Accepted: Apr 24, 2020

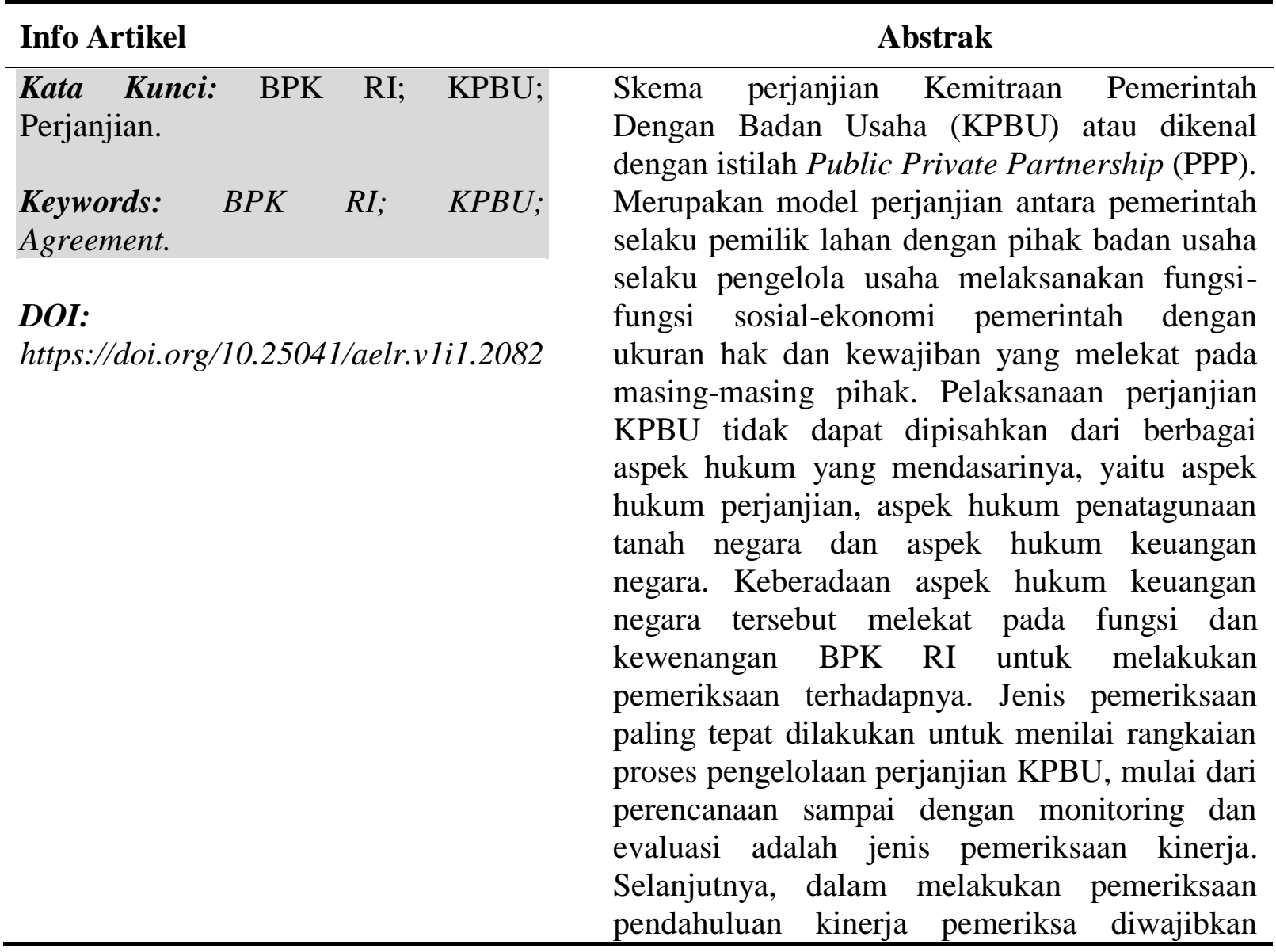


untuk dapat melakukan identifikasi permasalahan sebelum dilakukan pemeriksaan terinci. Terdapat beberapa permasalahan dasar yang diuraikan dalam tulisan ini, mulai dari proses perencanaan sampai dengan monitoring dan evaluasi yang perlu untuk ditindaklanjuti dengan menyusun langkah-langkah pemeriksaan yang kongkrit dan dapat diberikan suatu rekomendasi yang dapat diterapkan institusi.

Abstract
The scheme of the Government Partnership
Agreement with Business Entities (KPBUS) or
known as the Public Private Partnership (PPP).
It is a model agreement between the government
as the owner of the land and the business entity
as the business manager to carry out the socio-
economic functions of the government with the
size of the rights and obligations attached to
each party. The implementation of the PPP
agreement cannot be separated from the various
legal aspects that underlie it, namely the legal
aspects of the agreement, the legal aspects of
state land use and the legal aspects of state
finance. The existence of this legal aspect of
state finance is inherent in the function and
authority of BPK RI to conduct an examination
of it. The type of inspection that is most
appropriate for assessing the series of PPP
agreement management processes, from
planning to monitoring and evaluation is the
type of performance inspection. Furthermore, in
conducting a preliminary examination the
performance of the examiner is required to be
able to identify the problem before carrying out
a detailed examination. There are several basic
problems described in this paper, starting from
the planning process to monitoring and
evaluation that need to be followed up by
preparing concrete audit steps and a
recommendation that can be applied by the
institution.




\section{A. Pendahuluan}

Undang-Undang Nomor 23 Tahun 2014 tentang Pemerintahan Daerah telah memberikan otonomi yang seluas-luasnya kepada daerah guna mempercepat terwujudnya kesejahteraan masyarakat. Untuk mencapai tujuan tersebut maka pemerintah daerah diberikan kewenangan untuk melakukan kerjasama melalui program kemitraan dengan pihak swasta. ${ }^{1}$ Hal ini sejalan dengan pasal 278 ayat 1 Undang-Undang Nomor 23 Tahun 2014 tentang Pemerintahan Daerah yang mengatur jika penyelenggaraan Pemerintahan Daerah dapat melibatkan peran serta masyarakat dan sektor swasta dalam pembangunan Daerah ${ }^{2}$. Salah satu skema perjanjian dengan pihak swasta tersebut adalah melalui Kemitraan Pemerintah Dengan Badan Usaha (KPBU) atau dikenal dengan istilah Public Private Partnership (PPP). ${ }^{3}$

Implementasinya, pelaksanaan KPBU tidak dapat dipisahkan dari pertanggungjawaban pengelolaan keuangan negara dikarenakan perikatan yang terjadi antara pemerintah dengan swasta terdapat hak dan kewajiban, termasuk di dalamnya terdapat aliran transaksi dari dan ke kas negara atau daerah. Hipotesa atas peristiwa hukum tersebut adalah terjadinya berbagai jenis penyimpangan dalam pelaksanaannya yang berakibat pada terjadinya berbagai jenis penyimpangan dalam pelaksanaan perjanjian KPBU. ${ }^{4}$ Oleh karena itu, peran BPK RI diperlukan untuk melakukan pemeriksaan terhadapnya. Berdasarkan uraian di atas, penulis mencoba untuk membahas definisi KPBU, aspek hukum perjanjian pada KPBU, dan area potensial bermasalah (threat) pada KPBU yang dapat di jadikan indikasi permasalahan pada saat BPK RI melakukan perencanaan pemeriksaan. Tujuan dari penulisan jurnal ini adalah untuk mencoba mendalami aspek hukum yang perlu diperhatikan dalam melakukan pemeriksaan kinerja atas perjanjian dengan skema KPBU. Dalam menyusun jurnal ini, penulis mencoba untuk menggali informasi terkait area potensial bermasalah (threat) yang dapat dijadikan indikasi permasalahan ketika BPK RI melakukan perencanaan pemeriksaan perjanjian KPBU. Adapun data primer diperoleh melalui regulasi positif, pedoman di lingkungan BPK RI, buku dan jurnal ilmiah lainnya dengan rumusan masalah,bagaimanakah pemeriksaan yang perlu dilakukan dalam skema perjanjian jenis KPBU serta bagaimanakah peran Badan Pemeriksa Keuangan Republik Indonesia dalam melakukan pemeriksaan atas skema KPBU.

\section{B. Pembahasan}

\section{Skema Perjanjian KPBU}

Kerjasama Pemerintah dengan Badan Usaha (KPBU) atau pada beberapa praktik lainnya berdasarkan peraturan perundang-undangan dikenal dengan istilah Kerjasama Pemerintah dengan Swasta (KPS). Pengertian tersebut serupa dengan definisi public private partnership (PPP) pada skala internasional. KPBU adalah kerjasama yang memberikan kesempatan bagi sektor swasta untuk berpartisipasi dalam pembiayaan, desain, konstruksi, operasional dan pemeliharaan terhadap proyek/program sektor publik, umumnya pemanfaatan tanah/lahan negara. Melalui KPBU, keahlian dan aset dari kedua belah pihak antara pemerintah dan pihak swasta dapat bekerjasama menyediakan pelayanan kepada masyarakat ${ }^{5}$. Terdapat berbagai model KPBU yang biasa diterapkan, misalnya kontrak operasi dan pemeliharaan (Operate \& Maintenance Contract), Built Operate Transfer (BOT)/Bangun Guna Serah (BGS), dan Built

\footnotetext{
${ }^{1}$ Muhammad Dzikrullah H. Noho, "Memahami Hak dan Kewajiban Dalam Kebijakan Kerjasama Swasta Dengan Pemerintah Daerah (Pemda) Melalui Perjanjian Build Operate and Media, The Journal of Society and Media, Vol 3 No.1, (2018), hlm 53.

${ }^{2}$ Undang-undang No23 Tahun 2014 tentang Pemerintahan Daerah, pasal 278 ayat (1).

${ }^{3}$ Maman Suhendra, "Penyediaan Infrastruktur Dengan Skema Kerjasama Pemerintah dan Badan Usaha (Publik-Private) di Indonesia", Jurnal Manajemen Keuangan Publik", Vol 1 No.1, (2017), hlm 41-46.

${ }^{4}$ Waryanto, Siti Malikhatun Badriyah, Irawati, "Pengadaan Barang dan Jasa Yang Dilaksanakan Oleh Badan Usaha Milik Negara", Jurnal Notarius, Vol 13 No.2, (2020), hlm 704-706.

${ }^{5}$ Tim IIGF, Optimisme KPS di Indonesia, (Indonesia Infrastructure Guarantee Fund, 2013), hlm. 11.
} 
Transfer Operate (BTO)/Bangun Serah Guna (BSG), dan lainnya. ${ }^{6}$ Dalam pelaksanaannya, dasar hukum sebagai rujukan utama dalam pelaksanaan KPBU di Indonesia yakni:

1) Peraturan Pemerintah Nomor 27 tahun 2014 tentang Pengelolaan Barang Milik Negara;

2) Perpres Nomor 38 tahun 2015 tentang Kerjasama Pemerintah dengan Badan Usaha dalam Penyediaan Infrastruktur.

3) Permenko Nomor 04 tahun 2006 tentang Tata Cara Evaluasi Proyek Kerjasama Pemerintah dan Badan Usaha dalam Penyediaan Infrastruktur yang membutuhkan dukungan pemerintah.

4) Permen PPN Nomor 04 tahun 2010 tentang Panduan Umum Pelaksanaan Kerjasama Pemerintah dengan Badan Usaha dalam Penyediaan Infrastruktur;

5) Permen PPN Nomor 03 tahun 2012 tentang Panduan Umum Pelaksanaan Kerjasama Pemerintah Dengan Badan Usaha dalam Penyediaan Infrastruktur;

Lalu terdapat 3 (tiga) aspek hukum mendasar yang perlu dicermati dalam skema KPBU yakni pelaksanaan skema KPBU merupakan perjanjian antara dua subjek hukum badan hukum yaitu Penanggung Jawab Proyek Kerjasama (PJPK) dan Badan Usaha Pelaksana KPBU (BUP). Adapun PJPK adalah pihak pemerintah dalam hal ini Menteri, Kepala Lembaga Negara, Kepala Daerah atau Badan Usaha Milik Negara atau Daerah selaku penyedia atau penyelenggara infrastruktur ${ }^{7}$, sedangkan BUP adalah Badan Hukum berupa Perseroan Terbatas (PT) selaku penyedia infrastruktur ${ }^{8}$. Dalam kaitannya dengan syarat objektif sahnya perjanjian KPBU, diuraikan singkat sebagai berikut:

a. Causa yang halal, dalam hal ini objeknya perjanjian adalah limitatif pada 19 (Sembilan belas) sektor infrastruktur yang diatur di dalam pasal 5 ayat (1) Perpres KPBU; dan

b. Adanya objek tertentu, dalam hal ini objek perjanjian adalah pengelolaan infrastruktur yang dicantumkan dalam KPBU, termasuk penyediaan atau penyelenggaraan infrastruktur oleh pemerintah dan penyediaan infrastruktur oleh BUP, termasuk di dalamnya melekat hak dan kewajiban masing masing pihak seperti insentif, komitmen, pembayaran kepada BUP, pengelolaan infrastruktur oleh BUP dan sebagainya.

Berkaitan dengan skema perjanjian KPBU, lahan atau tanah yang dimanfaatkan oleh BUP untuk pemanfaatan dan operasional usaha merupakan tanah milik negara (Barang Milik Negara). ${ }^{9}$ Penulis menilai bahwa peran pemerintah dalam proses perencanaan harus memperhitungkan segala resiko dalam peruntukan lahan atau tanah tersebut sebagai lokasi operasional KPBU. ${ }^{10}$ Hal tersebut diperlukan misalnya untuk meminimalisir potensi rendahnya Return of Investment (RoI) di sisi pemerintah, kerugian dari sisi BUP atas lokasi lahan yang tidak komersil maupun potensi gugatan yang terjadi di masa yang akan datang. Hal ini sejalan dengan ketentuan dalam UU Nomor 5 tahun 1960 tentang Peraturan Dasar Pokok-Pokok Agraria yang mengatur bahwa pemerintah harus membuat perencanaan umum mengenai persedian, peruntukan dan penggunaan bumi, air dan ruang angkasa serta kekayaan alam yang terkandung di dalamnya ${ }^{11}$, termasuk untuk keperluan negara, pusat-pusat

\footnotetext{
${ }^{6}$ Joubert B. Maramis, "Faktor-Faktor Sukses Penerapan KPBU Sebagai Sumber Pembiayaan Infrastruktur : Suatu Kajian", Jurnal Manajemen Bisnis dan Inovasi, Vol 5 No.1, (2018), hlm 55-56.

7 Peraturan Presiden Nomor 38 tahun 2015 tentang Kerjasama Pemerintah dengan Badan Usaha dalam Penyediaan Infrastruktur, pada Pasal 1 angka 3.

${ }^{8} \mathrm{Ibid}$, pasal 1 angka 8.

${ }^{9}$ Shandi Patria Airlangga, "Hakikat Penguasa Dalam Negara Hukum Demokratis”, Jurnal Cepalo, Vol 3 No. 1, (2019), hlm 8.

${ }^{10}$ Towaf Totok Irawan, "Kajian Potensi dan Pembangunan Infrastruktur di Sektor Sosial Dengan Skema KBPU”, Jurnal Riset Manajemen dan Bisnis, Vol 1 No.2, (2016), hlm 118-199.

${ }^{11}$ Ahmad Redi, "Dinamika Konsepsi Penguasaan Negara Atas Sumber Daya Alam”, Jurnal Konstitusi, Vol 12 No.2, (2015), hlm 410-411.
} 
kehidupan masyarakat, sosial, kebudayaan dan lain kesejahteraan serta keperluan memperkembangkan industri, transmigrasi dan pertambangan ${ }^{12}$.

Konsep KPBU melibatkan adanya perjanjian kerjasama yang menimbulkan hak dan kewajiban para pihak yang dapat di ukur dengan uang, misalnya terkait:

1. Dukungan Kelayakan, yakni dukungan pemerintah dalam bentuk kontribusi fiskal yang bersifat finansial diberikan terhadap Proyek KPBU oleh Menteri Keuangan Negara dalam rangka meningkatkan kelayakan finansial dan efektifitas KPBU;

2. Insentif perpajakan kepada BUP;

3. Penjaminan Infrastruktur, yaitu pemberian jaminan atas kewajiban finansial PJPK yang dilaksanakan berdasarkan perjanjian penjaminan;

4. Pembayaran ketersediaan layanan, yaitu pembayaran secara berkala oleh Menteri/Kepala Lembaga/Kepala Daerah kepada BUP atas tersedianya layanan infrastruktur yang sesuai dengan kualitas dan/atau kriteria sebagaimana ditentukan dalam perjanjian KPBU;

Dikarenakan terjadinya perputaran uang masuk dan keluar dari kas negara atau daerah dalam konsep KPBU maka mandatory Badan Pemeriksa Keuangan Republik Indonesia (BPK RI) berdasarkan Undang-Undang Nomor 15 tahun 2004 tentang Pemeriksaan Pengelolaan dan Tanggung Jawab Keuangan Negara harus melaksanakan pemeriksaan atas pengelolaan dan tanggung jawab keuangan negara terhadapnya ${ }^{13}$. Namun, pembatasannya dengan dana pembayaran ketersediaan layanan yang sudah masuk dari negara atau daerah ke BUP, maka hal tersebut unauditable oleh BPK RI. ${ }^{14}$ Hal di atas dikarenakan dalam konteks pembahasan teori negara sebagai badan hukum publik, maka kedudukan hukum dari kekayaan negara harus dipisahkan antara kekayaan publik (domaine public) dan kekayaan privat (domaine prive $)^{15}$. Konsekuensinya adalah suatu kondisi abuse of power jika BPK RI memaksakan untuk melakukan pemeriksaan atas dana pembayaran ketersediaan layanan yang sudah masuk ke kas BUD (murni swasta). ${ }^{16}$ Adapun yang melakukan prosedur audit atas pengelolaan dan pertanggungjawaban dana tersebut seharusnya adalah Kantor Akuntan Publik (KAP).

\section{Pemeriksaan Oleh BPK RI}

Undang-Undang Nomor 15 tahun 2006 tentang Badan Pemeriksa Keuangan (BPK) mengatur BPK bertugas memeriksa pengelolaan dan tanggung jawab keuangan negara yang dilakukan oleh pemerintah pusat, pemerintah daerah, lembaga negara lainnya, Bank Indonesia, Badan Usaha Milik Negara (BUMN), Badan Layanan Umum (BLU), Badan Usaha Milik Daerah (BUMD), dan lembaga atau badan lain yang mengelola keuangan negara $^{17}$. Dalam melaksanakan fungsi dan tugas di atas, BPK mempunyai pedoman-pedoman pelaksana dan standar, seperti Standar Pemeriksaan Keuangan Negara (SPKN), Pedoman

\footnotetext{
12 UU Nomor 5 tahun 1960 tentang Peraturan Dasar Pokok-Pokok Agraria, pada pasal 14 ayat (1).

${ }^{13}$ Undang-Undang Nomor 15 tahun 2004 tentang Pemeriksaan Pengelolaan dan Tanggung Jawab Keuangan Negara, pada pasal 2 ayat (1).

${ }^{14}$ Arizon Mega Jaya, “Implementasi Perampasan Harta Kekayaan Pelaku Tindak Pidana Korupsi”, Jurnal Cepalo, Vol 1 No. 1, (2017), hlm 3.

15 Arifin P. Soeria Atmadja, Keuangan Publik dalam Perspektif Hukum, (Jakarta: PT. Rajagrafindo Persada, 2009), hal. 94.

${ }^{16}$ Kiki Kristanto, I Nyoman Nurjaya, Abdul Madjid, Prija Djatmika, "Ratio Legis Regulation of the BPK as the Only Once Authorized State Institution Declaring Countring Financial Damages in the President of 23 Paragraph (1) Change Constitution of the 1945 Constitution”, International Journal of Multicultural and Multireligious Understanding, Vol 7 Issue 2, (2020), Page 523-524.

${ }^{17}$ Undang-Undang Nomor 15 tahun 2006 tentang Badan Pemeriksa Keuangan, pada pasal 6 ayat (1).
} 
Manajemen Pemeriksaan (PMP), Standar Akuntansi Pemerintahan (SAP) dan Kode Etik Pemeriksaan. ${ }^{18}$

\section{a) Standar Dan Pedoman Dalam Pemeriksaan BPK}

Standar Pemeriksaan Keuangan Negara (SPKN) merupakan pijakan untuk melakukan pemeriksaan pengelolaan dan tanggungjawab keuangan negara ${ }^{19}$. BPK pun dalam menjalankan pemeriksaan pengelolaan dan tanggungjawab keuangan negara harus meliputi tahap perencanaan, pemeriksaan, pelaksanaan pemeriksaan, dan pelaporan pemeriksaan ${ }^{20}$ yang dilengkapi dengan Sistem Manajemen Mutu dan alur dokumentasi yang komprehensif untuk menghasilkan kualitas pemeriksaan yang sesuai dengan standar ${ }^{21}$. Selanjutnya, BPK menjalankan kewenangan Standar Akuntasi Pemerintahan (SAP) yang merupakan prinsipprinsip akuntansi yang diterapkan dalam menyusun dan menyajikan laporan keuangan pemerintah $^{22}$. Selain itu, BPK berpedoman terhadap Kode Etik BPK. Kode etik tersebut merupakan norma-norma yang harus dipatuhi oleh setiap anggota BPK dan Pemeriksa selama menjalankan tugasnya untuk menjaga martabat, kehormatan, citra, dan kredibilitas $\mathrm{BPK}^{23}$. Selain ke-empat standar dan pedoman di atas, masih terdapat banyak pedoman/petunjuk teknis (juknis) lain di lingkungan BPK RI, seperti Juklak/Juknis Pemeriksaan Laporan Keuangan, Juklak/Juknis Pemeriksaan Kinerja, dan Juklak/Juknis Pemeriksaan Dengan Tujuan Tertentu (PDTT).

BPK dalam melaksanakan tugas pokok dan fungsinya berwenang untuk melakukan 3 (tiga) jenis pemeriksaan, yaitu pemeriksaan keuangan, pemeriksaan kinerja, dan pemeriksaan dengan tujuan tertentu (PDTT), dengan uraian ${ }^{24}$ :

1. Pemeriksaan Keuangan, adalah pemeriksaan atas laporan keuangan pemerintah pusat dan pemerintah daerah. Pemeriksaan keuangan ini dilakukan oleh BPK dalam rangka memberikan pernyataan opini tentang tingkat kewajaran informasi yang disajikan dalam laporan keuangan pemerintah.

2. Pemeriksaan Kinerja, adalah pemeriksaan atas aspek ekonomi dan efisiensi, serta pemeriksaan atas aspek efektivitas yang lazim dilakukan bagi kepentingan manajemen oleh aparat pengawasan intern pemerintah.

3. Pemeriksaan Dengan Tujuan Tertentu (PDTT), adalah pemeriksaan yang dilakukan dengan tujuan khusus, di luar pemeriksaan keuangan dan pemeriksaan kinerja. Termasuk dalam pemeriksaan tujuan tertentu ini adalah pemeriksaan atas hal-hal lain yang berkaitan dengan keuangan dan pemeriksaan investigatif.

Petunjuk Pelaksanaan (Juklak) Pemeriksaan Kinerja BPK RI pada BAB IV tentang Perencanaan Pemeriksaan Kinerja mengatur, dalam melakukan pemeriksaan kinerja

\footnotetext{
18 Yayuk Harumiati dan Payamta, "Pengaruh Karakteristik Pemerintah Daerah dan Temuan Audit BPK Terhadap Kinerja Pemerintah Daerah Kabupaten/Kota di Indonesia Tahun Anggaran 2011”, Jurnal Akuntasi dan Pendidikan, Vol 3 No. 2 , (2014), hlm 78-79.

${ }^{19}$ Peraturan BPK RI Nomor 1 tahun 2017 tentang Standar Pemeriksaan Keuangan Negara, pada pasal 1 angka 2.

${ }^{20}$ Gilang Pramana Jasa, Ratna Herawati, “ Dinamika Relasi Antara Badan Pemeriksa Keuangan dan Dewan Perwakilan Rakyat Dalam Sistem Audit Keuangan Negara”, Jurnal Law Reform, Vol 13 No.2, (2017), hlm 192-195.

${ }^{21}$ Keputusan BPK RI Nomor 5/K/I-XIII.2/10/2015 tentang Pedoman Manajemen Pemeriksaan Badan Pemeriksa Keuangan, pada pasal 2.

${ }^{22}$ Peraturan Pemerintah Nomor 71 tahun 2010 tentang SAP, pada pasal 1 angka 3.

${ }^{23}$ Indra Yudha Koswara, "Kebijakan Hukum Pidana Terhadao Perhitungan Potensi Kerugian Negara”, Jurnal Ilmiah Hukum De Jure, Vol 4 No.1, (2019),, hlm 55-56.

${ }^{24}$ Mike Rayu Raba, "Peran Badan Pemeriksa Keuangan (BPK) Dalam Melakukan Pemeriksaan Terhadap Pengelolaan Keuangan Negara Untuk Mewujudkan Pemerintahan Yang Baik Menurut UU No. 15 Tahun 2006”, Jurnal Lex Crimen, Vol 6 No. 3, (2014), hlm 154-151.
} 
diperlukan adanya pemeriksaan pendahuluan. ${ }^{25}$ Karena salah satu tujuan pemeriksaan pendahuluan dituntut agar pemeriksa dapat mengidentifikasi permasalahan-permasalahan, termasuk potensi permasalahan yang akan dilakukan pemeriksaan secara mendalam pada pemeriksaan terinci ${ }^{26}$.

\section{Penutup}

Skema perjanjian Kemitraan Pemerintah Dengan Badan Usaha (KPBU) atau Public Private Partnership (PPP) merupakan perjanjian yang memberikan kesempatan bagi sektor swasta untuk berpartisipasi dalam pembiayaan, operasional serta pemeliharaan terhadap proyek atau program pemerintah dalam pemanfaatan tanah atau lahan negara. Dalam pelaksanaannya, telah diundangkan regulasi terkait pelaksanaan KPBU, khususnya Perpres Nomor 38 tahun 2015 tentang Kerjasama Pemerintah dengan Badan Usaha dalam Penyediaan Infrastruktur. Terdapat beberapa aspek hukum yang harus dicermati dalam pelaksanaan KPBU, yaitu aspek hukum perjanjian, aspek hukum pemanfaatan lahan negara dan aspek hukum keuangan Negara. Karena terdapat aspek hukum keuangan negara maka BPK RI berwenang untuk melakukan pemeriksaan atas pengelolaan perjanjian KPBU antara PJPK dengan BUP, termasuk dalam hal ini pemeriksaan pada aspek hukum perjanjian dan aspek hukum pemanfaatan lahan Negara. Dalam melakukan pemeriksaan, BPK RI terikat pada standar, pedoman, dan juknis yang sudah ditetapkan dan berlaku di lingkungan BPK RI. Sedangkan untuk pemeriksaan yang tepat untuk menilai keseluruhan siklus pengelolaan $\mathrm{KPBU}$, mulai dari perencanaan sampai dengan monitoring dan evaluasi, menurut penulis adalah jenis pemeriksaan kinerja.

Dalam kaitannya dengan pemeriksaan atas pengelolaan perjanjian KPBU, BPK dapat melakukannya dengan jenis pemeriksaan laporan keuangan, pemeriksaan kinerja maupun PDTT tergantung pada harapan penugasan dan tujuan pemeriksaan. Namun, jika hasil yang diharapkan dari pemeriksaan merupakan perbaikan tata kelola perjanjian KPBU dan menilai faktor 3E (efektivitas, efisiensi dan ekonomis) maka penulis menilai jenis pemeriksaan yang paling tepat dilakukan adalah pemeriksaan kinerja atas PJPK. Karena dalam pemeriksaan kinerja tidak hanya fokus pada implementasi faktor kepatuhan (compliance) perjanjian, tetapi juga menilai dari proses perencanaan sampai dengan pelaporan dan monitoring dan evaluasi (monev) dari pelaksanaan perjanjian KPBU.

\section{Daftar Pustaka}

A. Buku

Soeria Atmadja, Arifin P. 2009. Keuangan Publik dalam Perspektif Hukum. Jakarta: PT. Rajagrafindo Persada.

B. Jurnal

Ahmad Redi, "Dinamika Konsepsi Penguasaan Negara Atas Sumber Daya Alam", Jurnal Konstitusi, Vol 12 No.2, 2015. DOI: https://doi.org/10.31078/jk12210.

Arizon Mega Jaya, "Implementasi Perampasan Harta Kekayaan Pelaku Tindak Pidana Korupsi”, Jurnal Cepalo, Vol 1 No. 1, 2017. DOI: https://doi.org/10.25041/cepalo.v1no1.1752.

\footnotetext{
${ }^{25}$ Margareth Carla Rampengan, "Fungsi Laporan Hasil Pemeriksaan (LHP) Badan Pemeriksa Keuangan Dalam Kasus Tindak Pidana Korupsi”, Jurnal Lex Crimen, Vol 2 No.2, (2013), hlm 175-176.

${ }^{26}$ Petunjuk Pelaksanaan Pemeriksaan Kinerja, (BPK RI, 2017), pada BAB IV tentang Perencanaan Pemeriksaan Kinerja, huruf D.
} 
Gilang Pramana Jasa, Ratna Herawati, “ Dinamika Relasi Antara Badan Pemeriksa Keuangan dan Dewan Perwakilan Rakyat Dalam Sistem Audit Keuangan Negara”, Jurnal Law Reform, Vol 13 No.2, 2017. DOI: https://doi.org/10.14710/lr.v13i2.16155.

Indra Yudha Koswara, "Kebijakan Hukum Pidana Terhadao Perhitungan Potensi Kerugian Negara", Jurnal Ilmiah Hukum De Jure, Vol 4 No.1. 2019. DOI: http://dx.doi.org/10.35706/de'jure.v4i1.

Joubert B. Maramis, "Faktor-Faktor Sukses Penerapan KPBU Sebagai Sumber Pembiayaan Infrastruktur: Suatu Kajian”, Jurnal Manajemen Bisnis dan Inovasi, Vol 5 No.1, 2018. DOI: https://doi.org/10.35794/jmbi.v5i1.19149.

Kiki Kristanto, I Nyoman Nurjaya, Abdul Madjid, Prija Djatmika, "Ratio Legis Regulation of the BPK as the Only Once Authorized State Institution Declaring Countring Financial Damages in the President of 23 Paragraph (1) Change Constitution of the 1945 Constitution", International Journal of Multicultural and Multireligious Understanding, Vol 7 Issue 2, 2020. DOI: http://dx.doi.org/10.18415/ijmmu.v7i2.1522.

Maman Suhendra, "Penyediaan Infrastruktur Dengan Skema Kerjasama Pemerintah dan Badan Usaha (Publik-Private) di Indonesia", Jurnal Manajemen Keuangan Publik", Vol 1 No.1, 2017. DOI : http://dx.doi.org/10.31092/jmkp.v1i1.97.

Margareth Carla Rampengan, "Fungsi Laporan Hasil Pemeriksaan (LHP) Badan Pemeriksa Keuangan Dalam Kasus Tindak Pidana Korupsi”, Jurnal Lex Crimen, Vol 2 No.2, 2013.

Mike Rayu Raba, "Peran Badan Pemeriksa Keuangan (BPK) Dalam Melakukan Pemeriksaan Terhadap Pengelolaan Keuangan Negara Untuk Mewujudkan Pemerintahan Yang Baik Menurut UU No. 15 Tahun 2006." Jurnal Lex Crimen, Vol 6 No. 3. 2014.

Muhammad Dzikrullah H. Noho, "Memahami Hak dan Kewajiban Dalam Kebijakan Kerjasama Swasta Dengan Pemerintah Daerah (Pemda) Melalui Perjanjian Build Operate and Media, The Journal of Society and Media, Vol 3 No.1, (2018), DOI: 10.26740/jsm.v3n1.p51-67.

Putu Ika Wahyuni, Sarwono Hardjomuljadi, Hendrik Sulistio, dan Koespiadi. "Kajian Tata Ruang untuk Menerapkan Sistem Insentif Pemanfaatan Ruang pada Proyek KPS (Kerja Sama Pemerintah Swasta) Jalan Tol (Study Kasus Kaki Nusa Dua Pada Jalan Tol Bali Mandara)", Jurnal Paduraksa, Volume 7 Nomor 1, 2018.

Shandi Patria Airlangga, "Hakikat Penguasa Dalam Negara Hukum Demokratis", Jurnal Cepalo, Vol 3 No. 1, 2019. DOI: https://doi.org/10.25041/cepalo.v3no1.1783.

Towaf Totok Irawan, "Kajian Potensi dan Pembangunan Infrastruktur di Sektor Sosial Dengan Skema KBPU", Jurnal Riset Manajemen dan Bisnis, Vol 1 No.2, 2016. DOI: https://doi.org/10.36226/jrmb.v1i2.15.

Waryanto, Siti Malikhatun Badriyah, Irawati, "Pengadaan Barang dan Jasa Yang Dilaksanakan Oleh Badan Usaha Milik Negara", Jurnal Notarius, Vol 13 No.2, 2020. DOI : https://doi.org/10.14710/nts.v13i2.31095.

Wibowo, Andreas. "Opsi Terminasi Sebagai Instrumen Dukungan Pemerintah untuk Proyek Infrastruktur Berisiko Permintaan Tinggi". Jurnal Teknik Sipil, Vol. 22 No. 3, (2015), DOI: http://dx.doi.org/10.5614\%2Fjts.2015.22.3.3.

Yayuk Harumiati dan Payamta, "Pengaruh Karakteristik Pemerintah Daerah dan Temuan Audit BPK Terhadap Kinerja Pemerintah Daerah Kabupaten/Kota di Indonesia Tahun Anggaran 2011", Jurnal Akuntasi dan Pendidikan, Vol 3 No. 2, $2014 . \quad$ DOI: http://doi.org/10.25273/jap.v3i2.1244

C. Undang-undang

Pemerintah Indonesia. Keputusan BPK RI Nomor 5/K/I-XIII.2/10/2015 tentang Pedoman Manajemen Pemeriksaan Badan Pemeriksa Keuangan.

Pemerintah Indonesia. Peraturan BPK RI Nomor 1 tahun 2017 tentang Standar Pemeriksaan Keuangan Negara. Lembaran Negara RI Tahun 2017 Nomor 1. Sekretariat Negara. Jakarta.

Pemerintah Indonesia. Peraturan BPK RI Nomor 3 tahun 2016 tentang Kode Etik BPK. Lembaran Negara RI Tahun 2016 Nomor 143. Sekretariat Negara. Jakarta. 
Pemerintah Indonesia. Peraturan Pemerintah Nomor 71 tahun 2010 tentang SAP. Lembaran Negara RI Tahun 2010 Nomor 123. Sekretariat Negara. Jakarta.

Pemerintah Indonesia. Peraturan Presiden Nomor 38 tahun 2015 tentang Kerjasama Pemerintah dengan Badan Usaha dalam Penyediaan Infrastruktur. Lembaran Negara RI Tahun 2015 Nomor 62. Sekretariat Negara. Jakarta.

Pemerintah Indonesia. Petunjuk Pelaksanaan Pemeriksaan Kinerja Tahun 2017.

Pemerintah Indonesia. Undang-Undang Nomor 15 tahun 2004 tentang Pemeriksaan Pengelolaan dan Tanggung Jawab Keuangan Negara. Lembaran Negara RI Tahun 2004 Nomor 66. Sekretariat Negara. Jakarta.

Pemerintah Indonesia. Undang-Undang Nomor 15 tahun 2006 tentang Badan Pemeriksa Keuangan. Lembaran Negara RI Tahun 2006 Nomor 85. Sekretariat Negara. Jakarta.

Pemerintah Indonesia. Undang-Undang Nomor 5 tahun 1960 tentang Peraturan Dasar PokokPokok Agraria. Lembaran Negara RI Tahun 1960 Nomor 104. Sekretariat Negara. Jakarta.

D. Internet

Tim IIGF, Optimisme KPS di Indonesia. 2013. Indonesia Infrastructure Guarantee Fund. Tim IIGF. 
